\title{
DNA structure change induced by guanosine radicals - a theoretical and spectroscopic study
}

DNA structure change induced by radicals

\author{
J. Kobierski ${ }^{1}$, E. Lipiec
}

${ }^{1}$ corresponding author 


\section{Abstract}

Proton radiation therapy is one of the newest and most promising methods used in modern oncology. Nonetheless, the dissemination of that method may result challenging. This is partially due to the fact that the mechanism of DNA damage induced by protons, which is one of the ways proton radiation interacts with tissues, has not been fully understood yet. It is well known that ionizing radiation especially ions such as protons may directly damage DNA but it also causes the formation of radicals, which may lead to even more serious damage of the DNA sugar-backbone than direct interaction with charged ion. In this article we focus on the influence of guanine radicals on the DNA structure, namely the conformation and stability of the DNA strand. We present the theoretical results of the optimization calculations of DNA structures with guanine radical-adenine pairs as well as calculated Raman spectra. By combining theoretical calculations with the experimental spectra we were able to explain molecular modifications of the DNA sugar-backbone affected by guanine radicals formed upon radiation exposure, which lead to spectral changes between spectra of control and irradiated DNA. Thus we established a pathway of the formation of DNA damage caused by protons. 


\section{Introduction}

Proton therapy has been developing for over 60 years now. As far back as 1946 Robert Wilson proposed the use of accelerator-produced beams of protons to treat deep-seated tumors in the human body (1). Nine years later the first patient was treated with proton beams in the Lawrence Berkeley Laboratory (2). First ocular melanoma was exposed to protons in the mid-1970s (3). According to statistics of Particle Therapy Co-Operative Group, up to the present proton therapy has been used to treat 131240 patients in 46 centers worldwide (4). However, in comparison to other radiation therapies an adoption of proton therapy is fairly slow. One of the main reasons is the lack of knowledge about proton interaction with biomolecules.

DNA is the most sensitive biomolecule for radiation exposure $(5,6)$. A damaged lipid or protein molecule can be easily replaced, whereas damaged DNA must be repaired. Ionizing radiation can cause various types of DNA damage such as DNA strand cross-links, DNA-protein cross-links, Single Strand Breaks (SSBs), base damage, sugar damage and the most dangerous form Double Strand Break (DSBs). In eukaryotes DSBs are critical lesions that can lead to cell death (7).

DNA damage was investigated by plethora experimental and theoretical approaches. Comet assay, which is practically an electrophoresis of single cells, is commonly used in order to detect DNA strand breaks (8). Mass spectrometry and liquid chromatography are efficient tools used to investigate the chemical structure of damaged DNA $(9,10)$. All these experimental methods can affect DNA samples, leading to changes in their structure due to required DNA degradation or via application of chemical substances and complex preparation procedures (11). Raman spectroscopy, in turn, is a label free and non-invasive analytical technique, which can explore chemical structure of DNA damaged by radiation. However, 
Raman spectrum of such a complex molecule as DNA contains a lot of overlapping spectral features related to DNA functional groups. Therefore, an interpretation of spectral changes related with exposure to radiation can be problematic. In order to assign Raman bands and find the background of spectral changes related with irradiation we have proposed a combination of experimental and theoretical approach.

In the experimental Raman spectra an appearance of strong bands related to stretching of $\mathrm{C}=\mathrm{O}$ and $\mathrm{NH}_{2}$ banding mode from cytosine and guanine were observed after proton exposure. Therefore, we focused on guanine-cytosine pair and molecular changes, that could be a consequence of interaction with the guanine radical - the most frequently formed radical in the DNA structure. We optimized structures with radicals (not their products) in order investigate direct influence of guanine radicals on the local DNA structure and predict following molecular damage.

Many molecular processes can be simulated by the quantum mechanical calculations. Until now theoretical calculations, in particular Density Functional Theory (DFT), have been successfully used to present models explaining mechanism of DNA damage, including radiation induced DNA damage. Recently these calculations have been used to elucidate DNA strand breaks after irradiation, where ionization of the sugar phosphate backbone by water radicals $\cdot \mathrm{OH}$ or direct damage by ionizing particles were considered as the most likely mechanism of DNA lesions (12-14).

Part of research focused on the processes occurring within or around the nitrogen base pairs. Shimuzu et al. used DFT calculations in order to investigate dehydrogenation reaction between $\mathrm{GC}$ and AT base pairs and $\bullet \mathrm{OH}$ radical, which can be produced upon irradiation of DNA (15). Zhang and Eriksson focused, in turn, on intramolecular radical cross-link reactions in deoxyribonucleosides induced by $\bullet \mathrm{OH}(16)$. 
Guanine, among all the DNA bases, has the lowest ionization potential, which means that it is the main oxidation center in DNA $(17,18)$. For this reason, irradiation of DNA leads to the formation of a large number of oxidized guanine $\left(\mathrm{G}^{\circ+}\right)$. The oxidation of guanine itself and the formation of guanine neutral radicals $(\cdot \mathrm{G})$ in the GC pair have been thoroughly investigated. Studies include breaking hydrogen bonds in the GC pair $(19,20)$, the formation of crosslinked structures between DNA base pairs (21), or the formation of neighboring bases structures in single strained DNA (22). However, due to limited computing performance, each time only isolated base systems were taken into consideration. Up to the present no results on effects of the interaction disturbance between the nitrogen bases on the DNA backbone or the global double strained DNA structure have been reported.

It is known from previous research that oxidized guanine loses protons either from $\mathrm{N} 1$ or $\mathrm{N} 2$ site, forming neutral $\bullet \mathrm{G}_{\mathrm{N} 1}$ and $\cdot \mathrm{G}_{\mathrm{N} 2}$ radicals, respectively (23). In this work we present calculated Raman spectra for DNA with the normally bonded GC pair, the DNA with $\bullet \mathrm{G}_{\mathrm{N} 1} \mathrm{C}$ and $\bullet \mathrm{G}_{\mathrm{N} 2} \mathrm{C}$ pairs, and the DNA with the pair of cytosine and guanine with hydrogens detached from both $\mathrm{N} 1$ and $\mathrm{N} 2$ site $\cdot \mathrm{G}_{\mathrm{N} 1, \mathrm{~N} 2} \mathrm{C}$ (Figure 1) along with experimental Raman spectra of undamaged DNA and DNA irradiated by the dose of 4000 protons. By combining the experimental results with theoretical calculations we were able to establish the types of lesions produced by both proton radiation in DNA. Calculations were performed using Density Functional Theory (DFT). Apply of DFT allowed to obtain high precision for the GC pair. The rest of the system was treated classically using the ONIOM hybrid model. The ONIOM method was previously used for Raman spectra calculations of radiation-induced damaged DNA. Simulated spectra were in good agreement with the experimental data (24). Additionally, this model was successfully applied to study DNA interactions with metal complexes (25-27), chloridazon herbicide (28), and proflavine (29). 


\section{Materials and methods}

\section{Experimental procedures}

\section{DNA irradiation}

DNA plasmid pUC-18 (SIGMA Aldrich) was irradiated with $2 \mathrm{MeV}$ protons. A droplet of $2 \mu \mathrm{l}$ of DNA (concentration $0.5 \mu \mathrm{g} / \mu \mathrm{l})$ dissolved in buffer $(0.5 \mathrm{mg} / \mathrm{ml}$ in $10 \mathrm{mM}$ Tris $-\mathrm{HCl}$ with $1 \mathrm{mM}$ EDTA, $\mathrm{pH}$ 8.0) was deposited as a thin film on Mylar Foil (Goodfellow Cambridge Limited, Huntington, UK). The Cracow microbeam from the Van de Graaff accelerator was used as the proton source. Samples were irradiated in raster mode with the beam step comparable to the beam diameter $\sim 20 \mu \mathrm{m}$. The beam current was set to 4000 protons per sec. Two different protons numbers per raster step were applied: 400 and 4000 protons. After irradiation the samples were transferred onto aluminum coated $(80 \mathrm{~nm})$ Petri dishes (35 nm diameter) and measured using the Raman microscope.

\section{Raman spectroscopy and data processing}

Experimental Raman spectra were recorded using a WiTec Confocal Raman Microscope $\alpha-300 \mathrm{R}$ equipped with $\mathrm{Nd}-$ Yag $532 \mathrm{~nm}$ (green) laser with a CCD camera cooled to $-60^{\circ} \mathrm{C}$. 50x Zeiss objective was applied. Data were collected in the spectral range of $3700 \mathrm{~cm}^{-1}-200 \mathrm{~cm}^{-1}$. The acquisition time was 5-20 second per spectrum, depending on signal to noise ratio. The spectral resolution was $2 \mathrm{~cm}^{-1}$. Raman spectra were processed using Opus 6.5 software, which included smoothing (number of smoothing points: 13) and baseline correction (rubber-band correction, number of baseline points: 16, number of iterations 2-4). In these experiments spectra were vector normalized in the spectral range of $1800 \mathrm{~cm}^{-1}-250 \mathrm{~cm}^{-1}$ because of the variation in sample thickness. 


\section{Calculation procedures}

The DNA oligomer with the AGAGCTCT sequence in B conformation was chosen as a starting structure for optimization. Initial coordinates of atoms were taken from Nucleic Acid Database [http://ndbserver.rutgers.edu]. Geometry optimization and Raman activity calculations for undamaged and radiation-induce damaged (with neutral guanine radical in guanine-cytosine pair) DNA structures were carried out using GAUSSIAN 09 software package. Frequency calculations were performed based on previously optimized structures. All calculations were carried out using ONIOM model, with Becke-Half-and-Half-LYP Density Functional Theory method (BHandHLYP) (30) using 6-311++G(d,p) basis functions for one guanine-cytosine pair with adjacent deoxyribose molecules and a phosphate groups, and Universal Force Field model for additional 7 base pairs. BHandHLYP, a hybrid exchange-correlation functional, was reported as the best performer for the hydrogen-bonded base pairs systems (21). The system was optimized using default integration grid, default integral cutoffs and EDIIS+CDIIS convergence algorithm without damping.

Density Functional Theory methods are known to overestimate vibrational frequencies, which is caused by anharmonicity effects in the theoretical treatment. To avoid this factor and to eliminate known systematic errors resulting from fragmentary incorporation of electron correlation and the use of finite basis sets frequencies obtained from vibrational analysis were scaled by 0.967 factor.

Then, the theoretical Raman intensities were calculated according to the formula (31):

$$
I_{i}^{R}=C\left(v_{0}-v_{i}\right)^{4} v_{i}^{-1} B_{i}^{-1} S_{i}
$$

where $C$ is a constant given in arbitrary units, $S_{i}$ and $v_{i}$ are the Raman scattering activity and the frequency of the normal mode $Q_{i}$, respectively. $v_{0}$ is the frequency of the laser excitation line. In this work this frequency was taken $18797 \mathrm{~cm}^{-1}$, what corresponds to $532 \mathrm{~nm}$, 
a wavelength emitted by Nd:YAG laser used in experiments. $B_{i}$ is a temperature factor which accounts for the intensity contribution of excited vibrational states and is represented by the Boltzmann distribution:

$$
B_{i}=1-\exp \left(-\frac{h c v_{i}}{k T}\right)
$$

where $h, k, c$ are Planck constant, Boltzmann constant, and speed of light, respectively. $T$ stands for temperature, which was assumed $273.15 \mathrm{~K}$.

\section{Results and Discussion}

\section{DNA}

Figure 2 shows a comparison of an experimental spectrum collected from control DNA and theoretical spectrum, calculated for molecular system presented in Figure 3. Signal from DNA bases in both spectra is dominated by $v(\mathrm{C}=\mathrm{O})$ and $\delta\left(\mathrm{NH}_{2}\right)$ of cytosine and guanine, base stacking vibration at $\sim 1668 \mathrm{~cm}^{-1}(24,32-34)$, in plane ring vibration of cytosine and guanine as well as $\delta\left(\mathrm{NH}_{2}\right)$ in spectral range from $1570 \mathrm{~cm}^{-1}$ to $1630 \mathrm{~cm}^{-1}$ and $v(\mathrm{C}=\mathrm{N})$ of cytosine together with deformational motion $\mathrm{C}_{2} \mathrm{H}_{2}$ functional group $(34,35)$. Signal from the DNA backbone involves asymmetric and symmetric stretching of phosphate at $1220 \mathrm{~cm}^{-1}-$ $1250 \mathrm{~cm}^{-1}$, and at $1040 \mathrm{~cm}^{-1}-1110 \mathrm{~cm}^{-1}$ respectively and symmetric stretching vibration of $\mathrm{O}-\mathrm{P}-\mathrm{O}$ in the spectral range from $840 \mathrm{~cm}^{-1}$ to $770 \mathrm{~cm}^{-1}(24,34,36,37)$.

Spectra of damaged DNA (irradiated with the dose of 400 and 4000 protons) are presented in Figure 4. Spectra collected from irradiated DNA indicate an appearance of strong bands related to $\mathrm{C}=\mathrm{O}$ stretching and $\mathrm{NH}_{2}$ bending from cytosine and guanine. These bands were not observed after exposure to photons, as described in our previous work (24). Therefore we have assumed that these changes in Raman spectra are related either with the direct radiation 
damage caused by proton or are possibly related to interaction with guanine radicals, which are the most frequently formed radicals in the DNA structure. Hence, we have tested the hypothesis, that guanine radicals may locally destabilize DNA structure and cause permanent damage, that could be detected in Raman spectroscopy. The lifetime of guanine radicals is in the range of ms. However, they can permanently modify the molecular structure of the DNA backbone (38). We have optimized three DNA structures with various guanine radicals: $\cdot \mathrm{G}_{\mathrm{N} 1} \mathrm{C}, \cdot \mathrm{G}_{\mathrm{N} 2} \mathrm{C}, \cdot \mathrm{G}_{\mathrm{N} 1, \mathrm{~N} 2} \mathrm{C}$ and we deeply analyzed their influence on the local molecular structure of the DNA double strand. We generated Raman spectra and compared them with the experimental data to check whether we are able to detect these local molecular changes by Raman spectroscopy.

The experimental spectra for 400 and 4000 protons do not differ much from each other as presented in Fig. 4, therefore in the further analysis we focus only on the spectrum for a larger dose, namely 4000 protons. Detailed band wavenumbers and their assignment are reported in Table 1. Experimental data show that bands interpreted as a double bond stretching vibration $v(\mathrm{C}=\mathrm{O})$, scissoring vibration $\delta\left(\mathrm{NH}_{2}\right)$ and stretching vibration $v(\mathrm{C}=\mathrm{N})$ of bases cytosine and guanine at $1667 \mathrm{~cm}^{-1}$ and $1580 \mathrm{~cm}^{-1}$ are shifted after irradiation into $1751 \mathrm{~cm}^{-1}$. Band interpreted as symmetric stretching $v_{\mathrm{sym}}(\mathrm{O}-\mathrm{P}-\mathrm{O})$ at $1069 \mathrm{~cm}^{-1}$ is splitted after irradiation, whereas stretching vibration band $v(\mathrm{O}-\mathrm{P}-\mathrm{O})$ observed at $772 \mathrm{~cm}^{-1}$ in spectrum of control DNA is shifted into higher wavelength of $862 \mathrm{~cm}^{-1}$ in spectra of irradiated DNA.

All spectral changes of O-P-O bands are associated with conformational changes resulting in shortening or increasing the distance between base pairs. Conformation change require a modification of O-P-O bond length and O-P-O bond angle (Figure 3), which can be directly observed in Raman spectrum as shifts of $\mathrm{O}-\mathrm{P}-\mathrm{O}$ stretching vibrations related bands $(36,37)$. Therefore, here we are presenting O-P-O bond lengths and O-P-O bond angles obtained for each optimized DNA structure in order to monitor local conformational change induced by 
DNA damage. The averaged $\mathrm{O}-\mathrm{P}-\mathrm{O}$ bond angle in optimized structure of control DNA was equal to $108.85^{\circ} \pm 0.16^{\circ}$, whereas the averaged P-O bond length was $1.5826 \pm 0.0047 \AA$ (

Table 2 and Figure 5). Detailed bond length and angles are presented in Table 3. This distance is consistent with the results of crystallographic experiments by Langridge et al. which was $1.60 \AA$ (39).

\section{$\bullet \mathrm{G}_{\mathrm{N} 1} \mathrm{C}$}

Figure 6 shows experimental spectra of irradiated DNA and calculated spectrum of DNA with - $\mathrm{G}_{\mathrm{N} 1}$ radical in $\mathrm{GC}$ pair: $\mathrm{G}_{\mathrm{N} 1} \mathrm{C}$ (see Figure 7 for a schematic model). It can be seen, that modes which correspond to stretching vibration $v(\mathrm{C}=\mathrm{O})$ and scissoring vibration $\delta\left(\mathrm{NH}_{2}\right)$ are significantly separated and shifted into $1782 \mathrm{~cm}^{-1}$ and $1720 \mathrm{~cm}^{-1}$ of cytosine and $1680 \mathrm{~cm}^{-1}$ and $1636 \mathrm{~cm}^{-1}$ of guanine. The band $v_{\text {asym }}(\mathrm{O}-\mathrm{P}-\mathrm{O})$ and $v_{\mathrm{sym}}(\mathrm{O}-\mathrm{P}-\mathrm{O})$ are not significant in this calculation. Experimental peak at $862 \mathrm{~cm}^{-1}$ corresponds to calculated mode at $857 \mathrm{~cm}^{-1}$ of deoxyribose vibration and stretching vibration band $v(\mathrm{O}-\mathrm{P}-\mathrm{O})$. The $\mathrm{P}-\mathrm{O}$ bond length in this structure is $1.619 \pm 0.060 \AA$, while the angle of $\mathrm{O}-\mathrm{P}-\mathrm{O}$ band is smaller than in unchanged DNA and it equals $99.1^{\circ} \pm 2.2^{\circ}$. In this optimized structure we observed the shift of the bases with respect to each other and formation of "unnatural" base pair with only two hydrogen bonds, like in Reynisson work (20).

\section{$\cdot \mathrm{G}_{\mathrm{N} 2} \mathrm{C}$}

Spectrum calculated for DNA with $\cdot \mathrm{G}_{\mathrm{N} 2} \mathrm{C}$ pair compared with experimental spectra of irradiated DNA are presented in Figure 8. A schematic model of the optimized structure is shown in Figure 9. As in the case of DNA with $\cdot \mathrm{G}_{\mathrm{N} 1} \mathrm{C}$ pair, modes of stretching vibration $v(\mathrm{C}=\mathrm{O})$ of guanine and cytosine are shifted into $1788 \mathrm{~cm}^{-1}$ and $1760 \mathrm{~cm}^{-1}$, as well as scissoring vibration $\delta\left(\mathrm{NH}_{2}\right)$ of cytosine (to $\left.1708 \mathrm{~cm}^{-1}\right) . \delta\left(\mathrm{NH}_{2}\right)$ of guanine is absent, due to the lack of hydrogen at $\mathrm{N} 2$ site. Stretching vibration $v_{\text {sym }}(\mathrm{O}-\mathrm{P}-\mathrm{O})$ and $v(\mathrm{O}-\mathrm{P}-\mathrm{O})$ are shifted 
into $1070 \mathrm{~cm}^{-1}$ and $853 \mathrm{~cm}^{-1}$, respectively. The averaged $\mathrm{O}-\mathrm{P}-\mathrm{O}$ bonding angle is $97.9^{\circ} \pm 8.7^{\circ}$, whereas the averaged $\mathrm{P}-\mathrm{O}$ bond length is equal to $1.70 \pm 0.31 \AA$.

\section{$\cdot \mathrm{G}_{\mathrm{N} 1, \mathrm{~N} 2} \mathrm{C}$}

Calculated spectrum of DNA with $\cdot \mathrm{G}_{\mathrm{N} 2, \mathrm{~N} 2} \mathrm{C}$ pair and experimental spectra of irradiated DNA are presented in Figure 10. Figure 11 shows a schematic model of optimized structure. Stretching vibration $v(\mathrm{C}=\mathrm{O})$ of cytosine and guanine and scissoring vibration $\delta\left(\mathrm{NH}_{2}\right)$ of cytosine are shifted into $1782 \mathrm{~cm}^{-1}, 1756 \mathrm{~cm}^{-1}$, and $1720 \mathrm{~cm}^{-1}$, respectively. Symmetrical stretching vibration $v_{\mathrm{sym}}(\mathrm{O}-\mathrm{P}-\mathrm{O})$ is shifted into $1121 \mathrm{~cm}^{-1}$. The averaged $\mathrm{O}-\mathrm{P}-\mathrm{O}$ bond angle is in case of this structure $95.3^{\circ} \pm 3.1^{\circ}$ and the $\mathrm{P}-\mathrm{O}$ bond length is equal to $1.80 \pm 0.33 \AA$.

A direct comparison of experimental and theoretical spectra of control (not irradiated) DNA presented in Figure 2 proves proper selection of the theoretical molecular system as well as calculation procedure. High correlation between experimental and theoretical results is visible at first glance. Each marker band of DNA bases and the backbone, listed in results section, was observed in theoretical spectrum.

Proposed modifications of molecular system used for calculation allowed to explain spectral differences between experimental spectra of control and irradiated DNA (Figure 4). Our calculations show that the lack of the proton between the bases and consequently the break of hydrogen bond between these bases significantly changes the DNA structure. In the case of all simulated DNA damage, the presence of neutral guanine radical in guanine-cytosine pair results in an increase of the length of the $\mathrm{P}-\mathrm{O}$ bond in phosphate groups, while the $\mathrm{O}-\mathrm{P}-\mathrm{O}$ bonding angle in all optimized damaged structures decreases. As a consequence, the distance between base pairs is smaller than in the case of unchanged DNA, which suggests a local change of DNA conformation. 
Observed in experimental spectra peak split and shift of the band $v_{\text {sym }}(\mathrm{O}-\mathrm{P}-\mathrm{O})$ from $1069 \mathrm{~cm}^{-1}$ into $1017 \mathrm{~cm}^{-1}$, hence the change in potential of part of $\mathrm{O}-\mathrm{P}-\mathrm{O}$ bonds, also indicates that some amount of the DNA changes its conformation. This effect was observed in spectra calculated for DNA with $\cdot \mathrm{G}_{\mathrm{N} 2} \mathrm{C}$ and $\cdot \mathrm{G}_{\mathrm{N} 2, \mathrm{~N} 2} \mathrm{C}$ pairs. It is known that changes of band intensity of $v(\mathrm{O}-\mathrm{P}-\mathrm{O})$ at $1240 \mathrm{~cm}^{-1}, 1190 \mathrm{~cm}^{-1}$, and $1080 \mathrm{~cm}^{-1}$ in the DNA backbone are associated to strand breaks, whereas $v(\mathrm{C}-\mathrm{O})$ at $1060 \mathrm{~cm}^{-1}$ and $880 \mathrm{~cm}^{-1}$ to the structure change of sugar moiety (40).

Moreover, for calculations for DNA with $\bullet \mathrm{G}_{\mathrm{N} 2} \mathrm{C}$ and $\bullet \mathrm{G}_{\mathrm{N} 2, \mathrm{~N} 2} \mathrm{C}$ pairs we have observed an increase of $\mathrm{P}-\mathrm{O}$ bond lengths to the level above $2 \AA$ for one bond in case of $\bullet_{\mathrm{N} 2} \mathrm{C}$ and two bonds in case of $\cdot \mathrm{G}_{\mathrm{N} 2, \mathrm{~N} 2} \mathrm{C}$, while $\mathrm{P}-\mathrm{O}$ bonds in phosphate esters range within $1.59-1.63 \AA$. This extreme increase of bond lengths is related to the phosphodiester cleavage and the break of the DNA backbone (41).

The break of the hydrogen bond between the bases in the GC pair causes the rotation of these bases with respect to each other for all optimized structures of damaged DNA. This, in turn, prevents base stacking, one of the phenomena maintaining DNA. Such DNA structure is not stable anymore, which can explain the break of $\mathrm{P}-\mathrm{O}$ bonds in the DNA backbone. The shift of the so called base stacking mode $v(\mathrm{C}=\mathrm{O})$ can also be explained by the unstacking of bases caused by proton exposure (40), which can be seen in experimental as well as calculated spectra for all the three models of damaged DNA. This result shows that even one single local change in bonding between bases can result in the change of DNA conformation and may lead to the DNA strand break.

Our previous work indicated that the bond between carbon and oxygen from the DNA backbone is the most sensitive for the photon exposure and it breaks upon interaction with $\bullet \mathrm{H}$ and $\bullet \mathrm{OH}$ radicals (24). In contrast to our previous finding, in this article we prove that the 
interaction with guanine radicals may lead to the break of different P-O bonds included in the DNA backbone. Such radiation damage can be observed in Raman spectra. Raman markers of this radiation damage include i) an intensity decrease of the bands related with $v_{\text {sym }}(\mathrm{O}-\mathrm{P}-\mathrm{O})$ and $v_{\text {asym }}(\mathrm{O}-\mathrm{P}-\mathrm{O})$ and their shift towards higher energy (lower wavenumber) as presented in Table 1, ii) the appearance of $v(\mathrm{C}=\mathrm{O})$ and $\delta(\mathrm{NH} 2)$ from cytosine, base stacking vibration, and $v(\mathrm{C}=\mathrm{O})$ and $\delta\left(\mathrm{NH}_{2}\right)$ from guanine.

The same effect was observed by Zhu et al. in 2008. Using Raman spectroscopy the authors studied calf thymus DNA and nucleotides in aqueous solution after $9 \mathrm{~min}, 20 \mathrm{~min}$, and $40 \mathrm{~min}$ ultraviolet radiation exposure. The results proved that the influence of ultraviolet radiation is stronger on single nucleotides than on the whole DNA molecule. However, the authors proved that the molecular conformation of the DNA was changed and the hydrogen bonds were damaged. The researchers also described the interaction of UVR with purines and pyrimidines, which were badly damaged after exposure (42). Structural changes of double stranded DNA in aqueous solution induced by $\gamma$ radiation were studied by Fourier-Transform-Raman spectroscopy by Sailer et al. The authors put forward that intensity of the bands associated to T, A, G, C increases, which indicates unstacking of these bases (40). The same effect is observed in the presented research at $1335 \mathrm{~cm}^{-1}$ and $v(\mathrm{C}-\mathrm{N})$ at $1306 \mathrm{~cm}^{-1}$ in $\mathrm{C}$ and $\mathrm{G}(32)$.

\section{Conclusions}

In conclusion, we have demonstrated that the presence of a guanine radical in DNA double strand and hence the interaction disturbance between the nitrogen bases, which can be induced by proton radiation, has a significant effect on the DNA structure. This includes the change of DNA conformation as well as single or double break of DNA strand. High sensitivity of Raman spectroscopy allowed for detection of DNA radiation damage caused by 
exposure to $2 \mathrm{MeV}$ protons. Spectral changes related to radiation exposure were explained on the basis of theoretical DFT calculations. The combination of theoretical and experimental data proved that a small change in DNA bases such as oxidation of nitrogen destabilizes the DNA structure locally. Due to the weaker interaction between bases, the DNA backbone may locally change its conformation. These conformational changes determine DNA properties (43) and can affect the radiation sensitivity. Therefore, such results are of significant importance for radiation research.

\section{Acknowledgments}

This research project has been financed by the funds from the National Science Centre (Poland) granted on the basis of decision no. 2014/13/D/NZ1/01014. This research was supported in part by PL-Grid Infrastructure. Mr. Zbigniew Szklarz and Mr. Tomasz Pieprzyca are gratefully acknowledged for help in sample irradiation.

\section{References}

1. Wilson, R.R. 1946. Radiological Use of Fast Protons. Radiology. 47: 487-491.

2. Lawrence, J.H., C.A. Tobias, J.L. Born, R.K. McCombs, J.E. Roberts, H.O. Anger, B. V Low-Beer, and C.B. Huggins. 1958. Pituitary irradiation with high-energy proton beams: a preliminary report. Cancer Res. 18: 121-34.

3. Gragoudas, E.S., M. Goitein, L. Verhey, J. Munzenreider, M. Urie, H. Suit, and A. Koehler. 1982. Proton beam irradiation of uveal melanomas. Results of 5 1/2-year study. Arch. Ophthalmol. (Chicago, Ill. 1960). 100: 928-34.

4. Particle Therapy Patient Statistics (per end of 2015). www.ptcog.ch/archive/patient_statistics/Patientstatistics-updateDec2015.pdf.

5. Prise, K.M., G. Schettino, M. Folkard, and K.D. Held. 2005. New insights on cell death from radiation exposure. Lancet Oncol. 6: 520-528.

6. O'Neill, P., and P. Wardman. 2009. Radiation chemistry comes before radiation biology. Int. J. Radiat. Biol. 85: 9-25.

7. Ugenskiene, R., J. Lekki, W. Polak, K.M. Prise, M. Folkard, O. Veselov, Z. Stachura, W.M. Kwiatek, M. Zazula, and J. Stachura. 2007. Double strand break formation as a response to X-ray and targeted proton-irradiation. Nucl. Instruments Methods Phys. 
Res. Sect. B Beam Interact. with Mater. Atoms. 260: 159-163.

8. Dusinska, M., and A.R. Collins. 2008. The comet assay in human biomonitoring: geneenvironment interactions. Mutagenesis. 23: 191-205.

9. Dawidzik, J.B., H.B. Patrzyc, H. Iijima, E.E. Budzinski, A.J. Higbee, H.-C. Cheng, and H.C. Box. 2003. DNA damage measured by liquid chromatography-mass spectrometry in mouse fibroblast cells exposed to oxidative stress. Biochim. Biophys. Acta - Gen. Subj. 1621: 211-217.

10. Douki, T., and J.-L. Ravanat. 2014. Quantification of DNA Damage Using Mass Spectrometry Techniques. In: Gabelica V, editor. Nucleic Acids in the Gas Phase. Berlin, Heidelberg: Springer Berlin Heidelberg. pp. 203-224.

11. Jiang, Y., M. Rabbi, M. Kim, C. Ke, W. Lee, R.L. Clark, P.A. Mieczkowski, and P.E. Marszalek. 2009. UVA generates pyrimidine dimers in DNA directly. Biophys. J. 96: 1151-1158.

12. Lipiec, E., J. Czapla, J. Szlachetko, Y. Kayser, W. Kwiatek, B. Wood, G.B. Deacon, and J. Sá. 2014. Novel in situ methodology to observe the interactions of chemotherapeutical Pt drugs with DNA under physiological conditions. Dalton Trans. 43: $13839-44$.

13. Li, X., M.D. Sevilla, and L. Sanche. 2003. Density Functional Theory Studies of Electron Interaction with DNA: Can Zero eV Electrons Induce Strand Breaks? J. Am. Chem. Soc. 125: 13668-13669.

14. Abolfath, R.M., A.C.T. van Duin, and T. Brabec. 2011. Reactive Molecular Dynamics Study on the First Steps of DNA Damage by Free Hydroxyl Radicals. J. Phys. Chem. A. 115: 11045-11049.

15. Shimizu, E., Y. Tokuyama, N. Okutsu, K. Nomura, I. Victor, and N. Kurita. 2015. Attacking mechanism of hydroxyl radical to DNA base-pair : density functional study in vacuum and in water. J. Biomol. Struct. Dyn. 33: 158-166.

16. Zhang, R.B., and L.A. Eriksson. 2006. Theoretical study of the tandem cross-linkage lesion in DNA. Chem. Phys. Lett. 417: 303-308.

17. Kumar, A., and M.D. Sevilla. Theoretical Modeling of Radiation-Induced DNA Damage. Radic. Radic. Ion React. Nucleic Acid Chem. : 1-40.

18. Steenken, S. 1997. How easily oxidizable is DNA-one-electron reduction potentials of adenosine and guanosine radicals in aqueous-solution. J. Am. Chem. Soc. 119: 617618.

19. Bera, P.P., and H.F. Schaefer. 2005. (G-H)*-C and G-(C-H)* radicals derived from the guanine.cytosine base pair cause DNA subunit lesions. Proc. Natl. Acad. Sci. U. S. A. 102: 6698-6703.

20. Reynisson, J., and S. Steenken. 2002. DNA-base radicals. Their base pairing abilities as calculated by DFTElectronic supplementary information (ESI) available: Single-point energies, zero-point energies and BSSE corrections for guanine, 7,8-dihydro-8oxoguanine, their radicals and base pairs. Phys. Chem. Chem. Phys. 4: 5346-5352. 
21. Pottiboyina, V., A. Kumar, and M.D. Sevilla. 2011. Formation of N-N Cross-Links in DNA by Reaction of Radiation-Produced DNA Base Pair Diradicals: A DFT Study. J. Phys. Chem. B. 115: 15090-15097.

22. Wang, S., M. Zhang, P. Liu, S. Xie, F. Cheng, and L. Wang. 2017. DNA intrastrand cross-links induced by the purine-type deoxyguanosine-8-yl radical: a DFT study. Phys. Chem. Chem. Phys. 19: 16621-16628.

23. Adhikary, A., A. Kumar, S.A. Munafo, D. Khanduri, and M.D. Sevilla. 2010. Prototropic equilibria in DNA containing one-electron oxidized GC: intra-duplex vs. duplex to solvent deprotonation. Phys. Chem. Chem. Phys. 12: 5353.

24. Lipiec, E., R. Sekine, J. Bielecki, W.M. Kwiatek, and B.R. Wood. 2014. Molecular characterization of DNA double strand breaks with tip-enhanced Raman scattering. Angew. Chemie - Int. Ed. 53: 169-172.

25. Gkionis, K., and J.A. Platts. 2009. QM/MM investigation into binding of square-planar platinum complexes to DNA fragments. J. Biol. Inorg. Chem. 14: 1165-1174.

26. Robertazzi, A., and J.A. Platts. 2006. A QM/MM study of cisplatin-DNA oligonucleotides: From simple models to realistic systems. Chem. - A Eur. J. 12: 57475756.

27. Gkionis, K., and J.A. Platts. 2012. QM/MM studies of cisplatin complexes with DNA dimer and octamer. Comput. Theor. Chem. 993: 60-65.

28. Ahmadi, F., N. Jamali, S. Jahangard-Yekta, B. Jafari, S. Nouri, F. Najafi, and M. Rahimi-Nasrabadi. 2011. The experimental and theoretical QM/MM study of interaction of chloridazon herbicide with ds-DNA. Spectrochim. Acta - Part A Mol. Biomol. Spectrosc. 79: 1004-1012.

29. Ruiz, R., B. García, G. Ruisi, A. Silvestri, and G. Barone. 2009. Computational study of the interaction of proflavine with d(ATATATATAT)2and d(GCGCGCGCGC)2. J. Mol. Struct. THEOCHEM. 915: 86-92.

30. Becke, A.D. 1993. A new mixing of Hartree-Fock and local density-functional theories. J. Chem. Phys. 98: 1372-1377.

31. Michalska, D., and R. Wysokiński. 2005. The prediction of Raman spectra of platinum(II) anticancer drugs by density functional theory. Chem. Phys. Lett. 403: 211-217.

32. Olsztynska-Janus, S., M. Gasior-Glogowska, K. Szymborska-Malek, M. Komorowska, W. Witkiewicz, C. Pezowicz, S. Szotek, and M. Kobielarz. 2012. Spectroscopic techniques in the study of human tissues and their components . Part II : Raman spectroscopy. Acta Bioeng. Biomech. 14: 121-133.

33. Jang, N.H. 2002. The coordination chemistry of DNA nucleosides on gold nanoparticles as a probe by SERS. Bull. Korean Chem. Soc. 23: 1790-1800.

34. Thomas, G.J., and M. Tsuboi. 1993. Raman spectroscopy of nucleic acids and their complexes. In: Advances in Biophysical Chemistry. Greenwich, CT: JAI Press. pp. 170 . 
35. Movileanu, L., J.M. Benevides, and G.J. Thomas. 2002. Temperature dependence of the Raman spectrum of DNA. II. Raman signatures of premelting and melting transitions of poly $(\mathrm{dA}) \cdot \operatorname{poly}(\mathrm{dT})$ and comparison with poly $(\mathrm{dA}-\mathrm{dT}) \cdot \operatorname{poly}(\mathrm{dA}-\mathrm{dT})$. Biopolymers. 63: 181-194.

36. Japaridze, A., D. Vobornik, E. Lipiec, A. Cerreta, J. Szczerbinski, R. Zenobi, and G. Dietler. 2016. Toward an Effective Control of DNA's Submolecular Conformation on a Surface. Macromolecules. 49: 643-652.

37. Treffer, R., X. Lin, E. Bailo, T. Deckert-Gaudig, and V. Deckert. 2011. Distinction of nucleobases - A tip-enhanced Raman approach. Beilstein J. Nanotechnol. 2: 628-637.

38. Rokhlenko, Y., N.E. Geacintov, and V. Shafirovich. 2012. Lifetimes and reaction pathways of guanine radical cations and neutral guanine radicals in an oligonucleotide in aqueous solutions. J. Am. Chem. Soc. 134: 4955-4962.

39. Langridge, R., D.A. Marvin, W.E. Seeds, H.R. Wilson, C.W. Hooper, M.H.F. Wilkins, and L.D. Hamilton. 1960. The molecular configuration of deoxyribonucleic acid II. Molecular Models and their Fourier Transforms. J. Mol. Biol. 2: 38-64.

40. Sailer, K. 1996. Radiation-induced structural modifications in dsDNA analysed by FTRaman spectroscopy. Int. J. Radiat. Biol. 69: 601-613.

41. Nakamoto, K., M. Tsuboi, and G.D. Strahan. 2008. Drug-DNA Interactions: Structures and Spectra. .

42. Zhu, J., Y. Zhang, L. Wu, Z. Wang, and Z. Sun. 2008. Dependence of surfaceenhanced Raman scattering from Calf thymus DNA on anions. Chinese Opt. Lett. 6: $526-529$.

43. Wood, B.R. 2016. The importance of hydration and DNA conformation in interpreting infrared spectra of cells and tissues. Chem. Soc. Rev. 45: 1980-1998. 


\section{Tables}

Table 1. Detailed Band assignments for experimental and calculated Raman spectra od undamaged and irradiated DNA $(24,32-37)$

\begin{tabular}{|c|c|c|c|c|c|c|}
\hline $\begin{array}{l}\text { DNA } \\
\text { control }\end{array}$ & $\begin{array}{l}\text { Simulated } \\
\text { DNA }\end{array}$ & $\begin{array}{l}\text { Irradiated } \\
\text { DNA }\end{array}$ & $\begin{array}{l}\text { DNA } \\
\text { with } \\
\cdot \mathrm{G}_{\mathrm{N} 1} \mathrm{C}\end{array}$ & $\begin{array}{l}\text { DNA } \\
\text { with } \\
\cdot \mathrm{G}_{\mathrm{N} 2} \mathrm{C}\end{array}$ & $\begin{array}{l}\text { DNA with } \\
\cdot \mathrm{G}_{\mathrm{N} 2, \mathrm{~N} 2} \mathrm{C}\end{array}$ & Assignment \\
\hline \multirow[t]{3}{*}{1667} & \multirow[t]{3}{*}{1668} & \multirow{6}{*}{1751} & 1782 & 1788 & 1782 & $\begin{array}{l}v(\mathrm{C}=\mathrm{O}), \delta\left(\mathrm{NH}_{2}\right) \text { of } \\
\mathrm{C} \text {, base stacking } \\
\text { vibration }\end{array}$ \\
\hline & & & \multirow{2}{*}{1720} & 1760 & 1756 & $v(\mathrm{C}=\mathrm{O})$ of $\mathrm{G}$ \\
\hline & & & & - & - & $\delta\left(\mathrm{NH}_{2}\right)$ of $\mathrm{G}$ \\
\hline \multirow{3}{*}{$\begin{array}{l}1570- \\
1630\end{array}$} & 1627 & & 1680 & 1708 & 1720 & $\begin{array}{l}\delta\left(\mathrm{NH}_{2}\right) \text {, in plane } \\
\text { ring vibration of C }\end{array}$ \\
\hline & \multirow[b]{2}{*}{1570} & & \multirow[b]{2}{*}{1636} & - & - & $\delta\left(\mathrm{NH}_{2}\right)$ of $\mathrm{G}$ \\
\hline & & & & 1602 & 1712 & $\begin{array}{l}\text { in plane ring } \\
\text { vibration of } G\end{array}$ \\
\hline \multirow{2}{*}{$\begin{array}{c}1430- \\
1580\end{array}$} & 1506 & \multirow[t]{2}{*}{1460} & - & - & 1574 & $\begin{array}{l}v(\mathrm{C}=\mathrm{N}) \text { of } \mathrm{C}, \text { def. } \\
\mathrm{C}_{2} \mathrm{H}_{2}\end{array}$ \\
\hline & 1439 & & - & - & 1538 & $v(\mathrm{C}=\mathrm{N})$ of $\mathrm{G}$ \\
\hline $\begin{array}{c}1220- \\
1250\end{array}$ & 1230 & 1250 & - & - & - & $v_{\text {asym }}(\mathrm{O}-\mathrm{P}-\mathrm{O})$ \\
\hline \multirow{2}{*}{$\begin{array}{l}1040- \\
1110\end{array}$} & \multirow{2}{*}{1037} & 1117 & \multirow{2}{*}{-} & \multirow{2}{*}{1070} & \multirow{2}{*}{1121} & \multirow{2}{*}{$v_{\text {sym }}(\mathrm{O}-\mathrm{P}-\mathrm{O})$} \\
\hline & & 1040 & & & & \\
\hline 772 & 833 & 862 & 857 & 853 & - & $\begin{array}{l}v(\mathrm{O}-\mathrm{P}-\mathrm{O}) \text { and } \\
\text { deoxyribose } \\
\text { vibration }\end{array}$ \\
\hline
\end{tabular}

Table 2. Averaged $\mathrm{O}-\mathrm{P}-\mathrm{O}$ bond angles and $\mathrm{P}-\mathrm{O}$ bond lengths obtained in calculations for unchanged DNA and DNA with neutral guanine radicals in GC pair

\begin{tabular}{|l|l|l|l|l|}
\hline & DNA control & $\bullet \mathrm{G}_{\mathrm{N} 1} \mathrm{C}$ & $\cdot \mathrm{G}_{\mathrm{N} 2} \mathrm{C}$ & $\cdot \mathrm{G}_{\mathrm{N} 2, \mathrm{~N} 2} \mathrm{C}$ \\
\hline $\mathrm{O}-\mathrm{P}-\mathrm{O}$ bond angles & $108.85^{\circ} \pm 0.16^{\circ}$ & $99.1^{\circ} \pm 2.2^{\circ}$ & $97.9^{\circ} \pm 8.7^{\circ}$ & $95.3^{\circ} \pm 3.1^{\circ}$ \\
\hline $\mathrm{P}-\mathrm{O}$ bond lengths & $1.5826 \pm 0.0047$ & $1.619 \pm 0.060$ & $1.70 \pm 0.31$ & $1.80 \pm 0.33$ \\
\hline
\end{tabular}


Table 3. $\mathrm{P}-\mathrm{O}$ bond lengths and $\mathrm{O}-\mathrm{P}-\mathrm{O}$ bond angles obtained in calculations for unchanged DNA and DNA with neutral guanine radicals in GC pair. For atoms labels explanation see Figure 3, 7, 9, and 11

\begin{tabular}{|l|l|l|l|l|l|l|l|}
\hline & & $\begin{array}{l}\mathrm{O}(1)-\mathrm{P}(2) \\
\text { distance }(\AA)\end{array}$ & $\begin{array}{l}\mathrm{P}(2)-\mathrm{O}(3) \\
\text { distance }(\AA)\end{array}$ & $\begin{array}{l}\mathrm{O}(1)-\mathrm{P}(2)- \\
\mathrm{O}(3) \text { angle }\end{array}$ & $\begin{array}{l}\mathrm{O}(4)-\mathrm{P}(5) \\
\text { distance }(\AA)\end{array}$ & $\begin{array}{l}\mathrm{P}(5)-\mathrm{O}(6) \\
\text { distance }(\AA)\end{array}$ & $\begin{array}{l}\mathrm{O}(4)-\mathrm{P}(5)- \\
\mathrm{O}(6) \text { angle }\end{array}$ \\
\hline \multirow{2}{*}{$\begin{array}{l}\text { DNA } \\
\text { control }\end{array}$} & $\mathrm{G}$ site & 1.59 & 1.58 & $109.09^{\circ}$ & 1.59 & 1.58 & $108.66^{\circ}$ \\
\cline { 2 - 8 } & $\mathrm{C}$ site & 1.58 & 1.59 & $108.81^{\circ}$ & 1.58 & 1.59 & $108.85^{\circ}$ \\
\hline \multirow{2}{*}{$\mathrm{G}_{\mathrm{N} 1 \mathrm{C}} \mathrm{C}$} & $\mathrm{G}$ site & 1.57 & 1.64 & $98.47^{\circ}$ & 1.58 & 1.57 & $102.64^{\circ}$ \\
\cline { 2 - 8 } & $\mathrm{C}$ site & 1.70 & 1.55 & $98.36^{\circ}$ & 1.62 & 1.72 & $96.81^{\circ}$ \\
\hline \multirow{6}{*}{$\mathrm{G}_{\mathrm{N} 2} \mathrm{C}$} & $\mathrm{G}$ site & 1.57 & 1.58 & $99.53^{\circ}$ & 1.58 & 1.57 & $103.09^{\circ}$ \\
\cline { 2 - 8 } & $\mathrm{C}$ site & 1.58 & 2.53 & $83.41^{\circ}$ & 1.58 & 1.59 & $105.74^{\circ}$ \\
\hline \multirow{2}{*}{$\mathrm{G}_{\mathrm{N} 2, \mathrm{~N} 2}$} & $\mathrm{G}$ site & 1.58 & 2.08 & $92.34^{\circ}$ & 2.57 & 1.57 & $92.50^{\circ}$ \\
\cline { 2 - 8 } $\mathrm{C}$ & $\mathrm{C}$ site & 1.68 & 1.55 & $99.87^{\circ}$ & 1.63 & 1.72 & $96.31^{\circ}$ \\
\hline
\end{tabular}

\section{Figures}

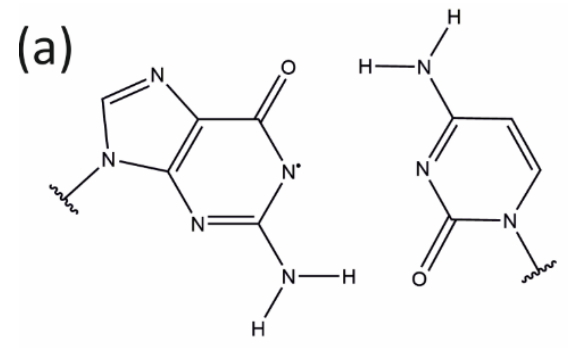

(b)

(c)<smiles></smiles>

Figure 1. Chemical structural formula of $\cdot \mathrm{G}_{\mathrm{N} 1} \mathrm{C}$ pair $(\mathrm{a}), \cdot \mathrm{G}_{\mathrm{N} 2} \mathrm{C}$ pair (b), and $\bullet \mathrm{G}_{\mathrm{N} 1, \mathrm{~N}_{2}} \mathrm{C}$ pair (c) 


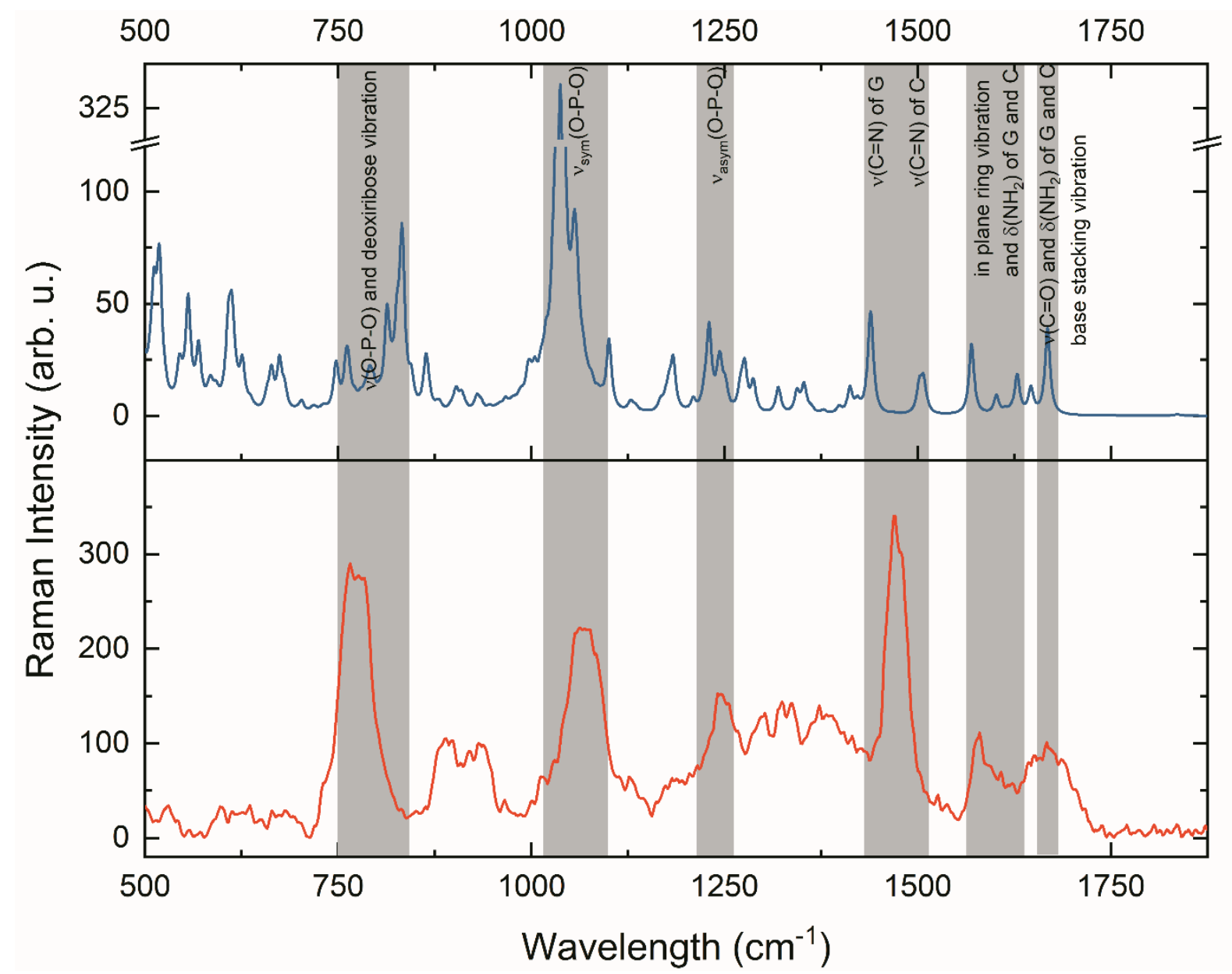

Figure 2. Experimental Raman spectrum along (red) with calculated Raman spectrum of undamaged DNA (blue)

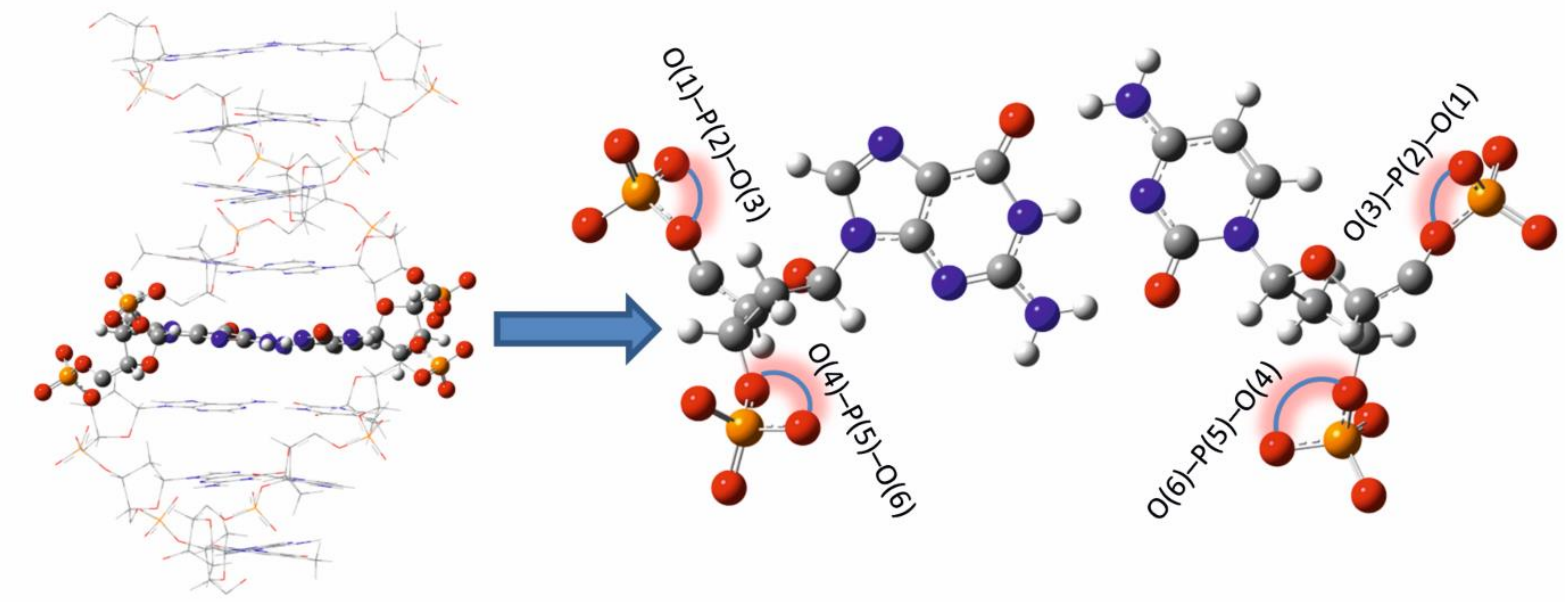

Figure 3. Schematic model of the theoretical molecular system of DNA (left) in which one GC pair (right) was treated quantum mechanically. 


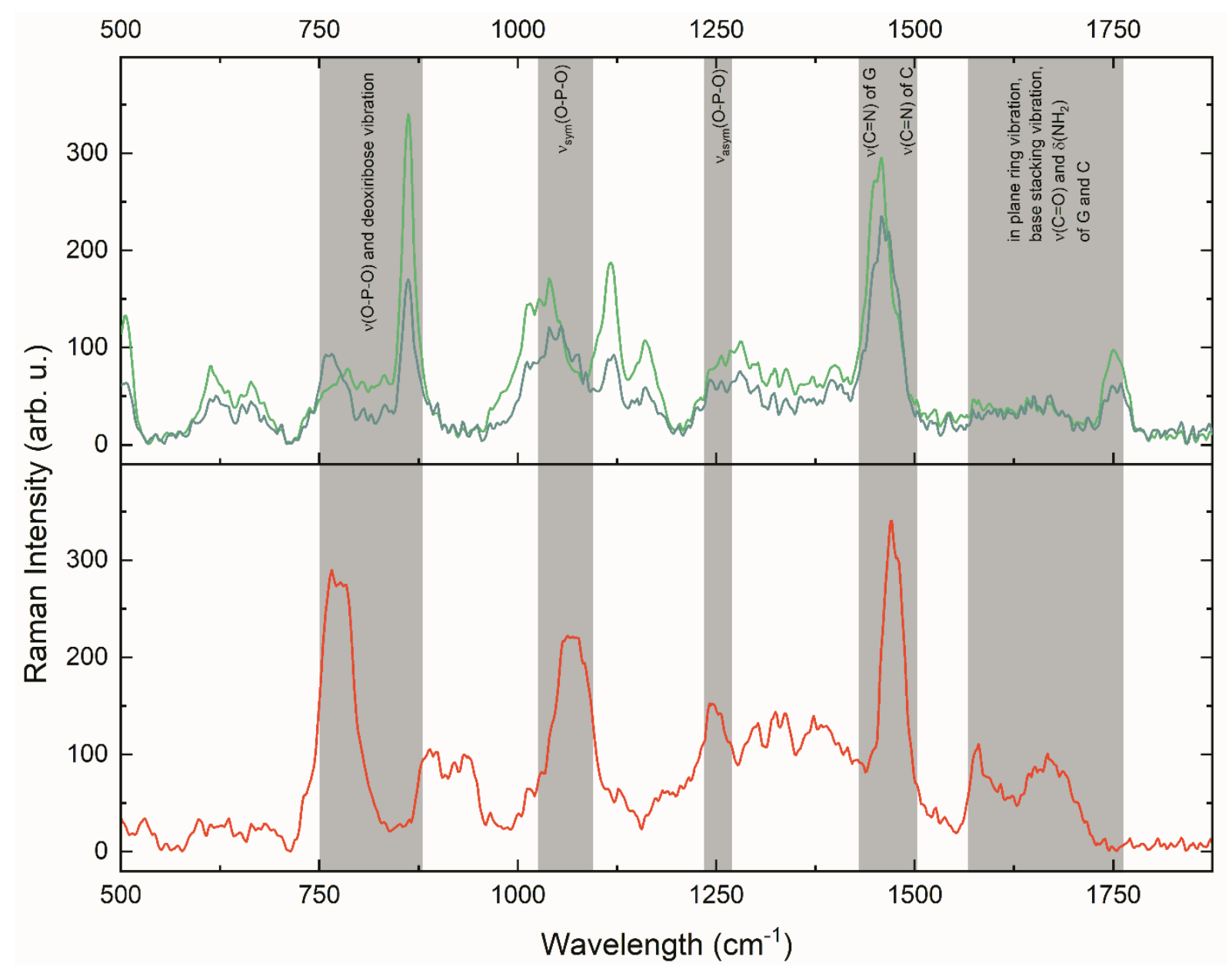

Figure 4. The comparison of experimental spectra of undamaged DNA (red) and DNA irradiated with the dose of 400 protons (cyan) 4000 protons (lime green) 


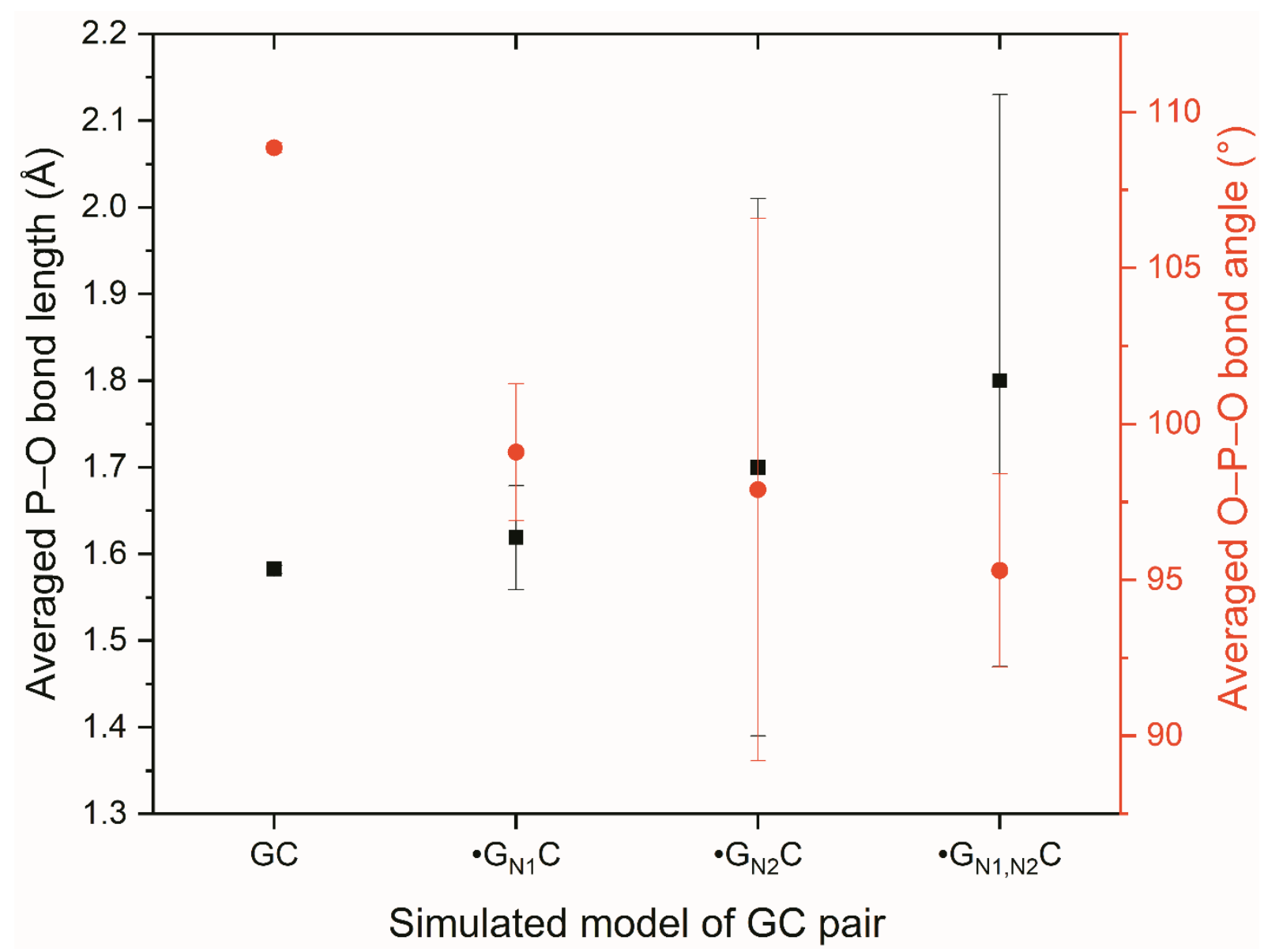

Figure 5. Averaged $\mathrm{P}-\mathrm{O}$ bond lengths (black squares) and $\mathrm{O}-\mathrm{P}-\mathrm{O}$ bond angles (red circles) obtained in calculations for unchanged DNA and DNA with neutral guanine radicals in GC pair 


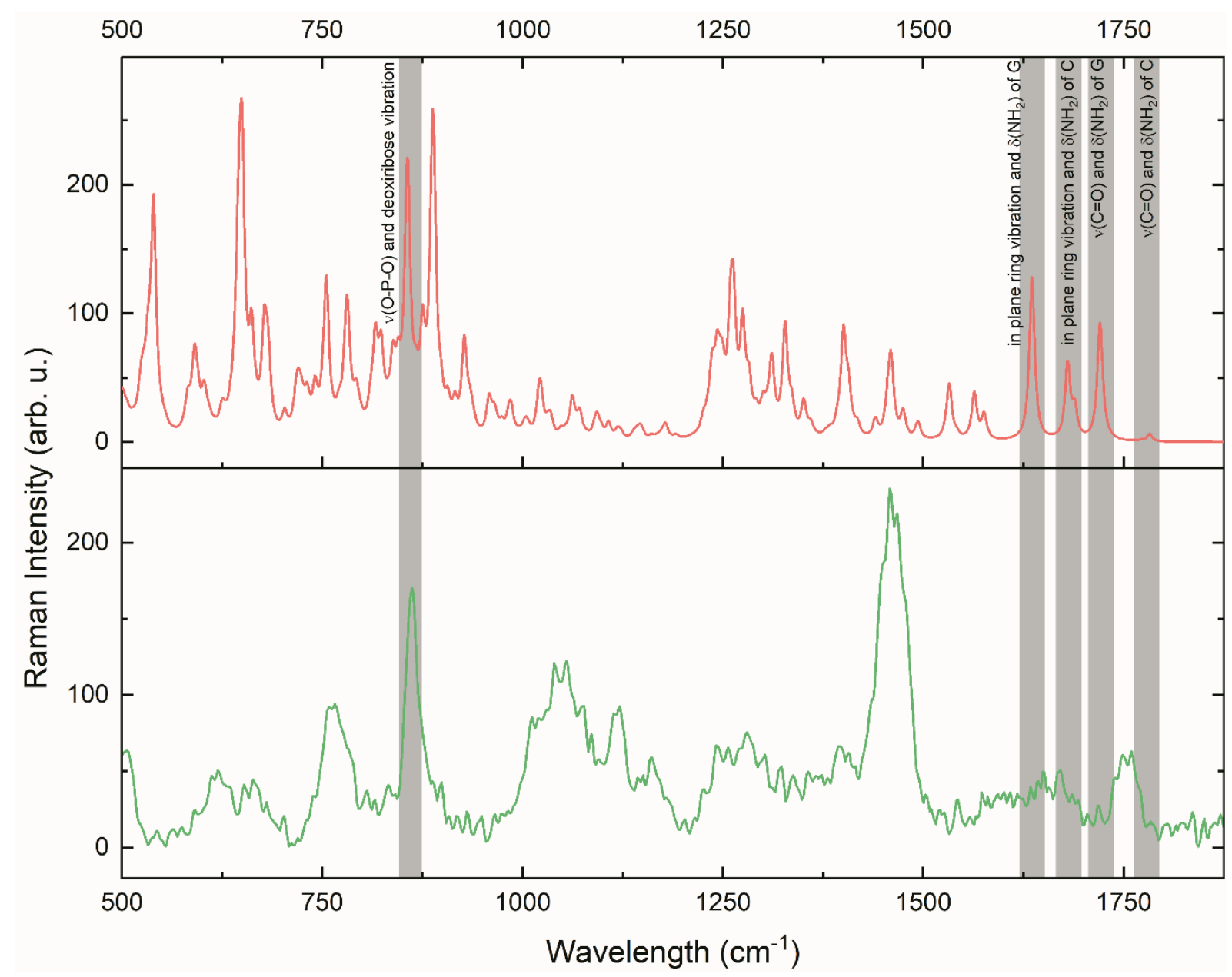

Figure 6. The comparison of spectra of DNA irradiated with the dose of 4000 protons (lime green) with calculated Raman spectrum of damaged DNA with $\cdot \mathrm{G}_{\mathrm{N} 1} \mathrm{C}$ pair (light red)

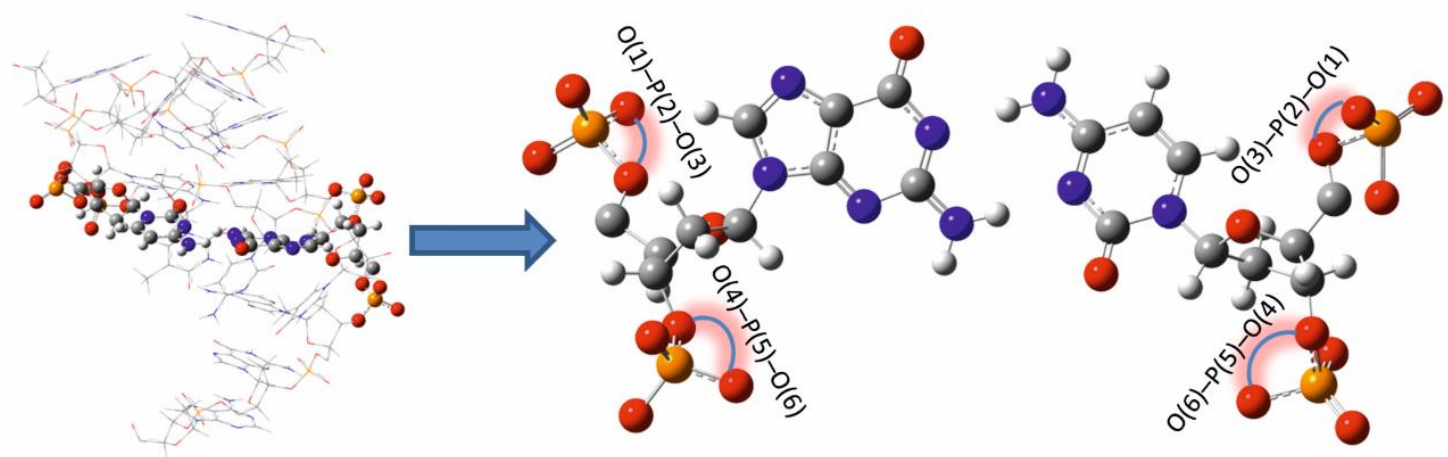

Figure 7. Schematic model of the theoretical molecular system of DNA (left) with $\cdot \mathrm{G}_{\mathrm{N} 1} \mathrm{C}$ pair (right) treated quantum mechanically 


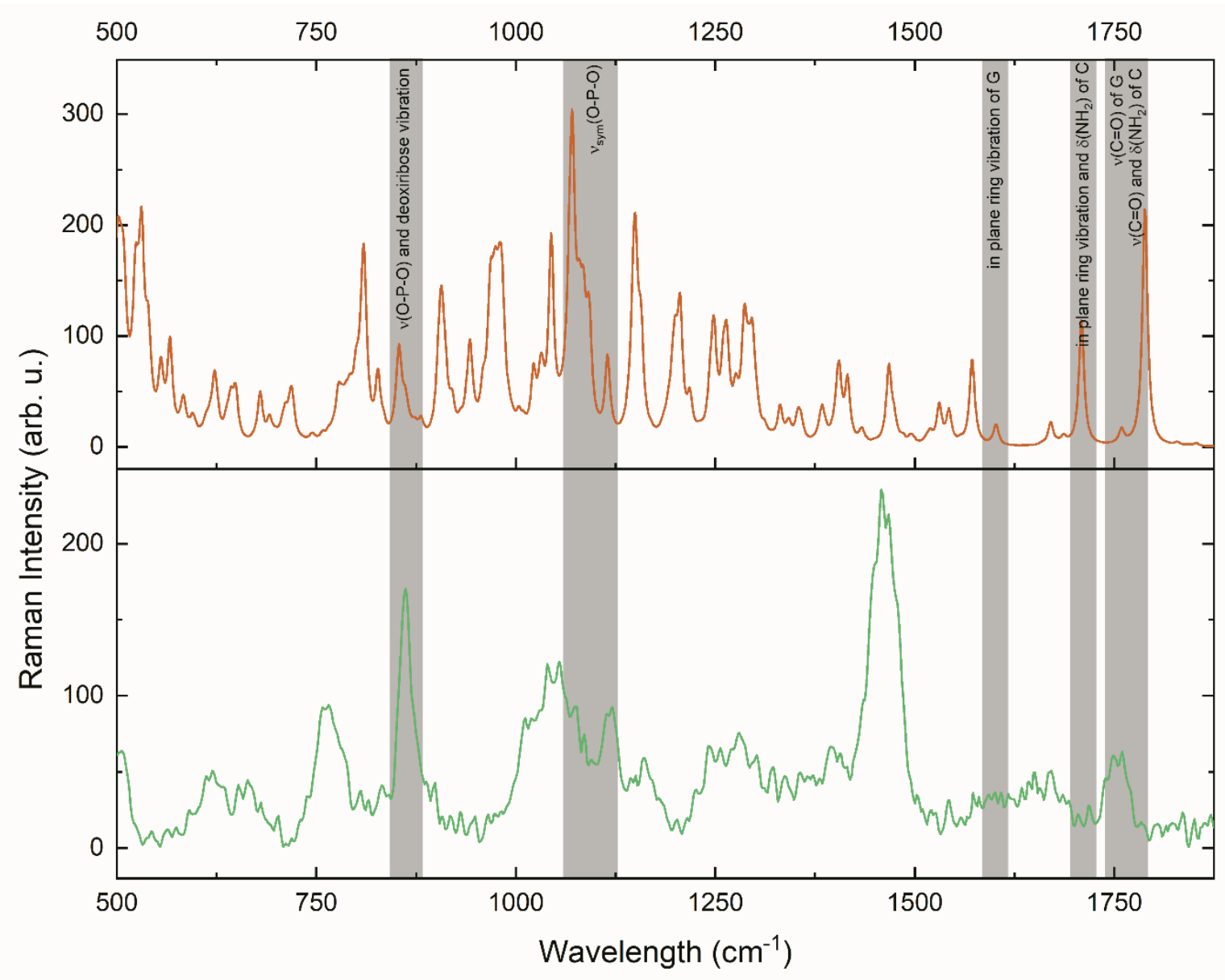

Figure 8. The comparison of spectra of DNA irradiated with the dose of 4000 protons (lime green) with calculated Raman spectrum of damaged DNA with $\cdot \mathrm{G}_{\mathrm{N} 2} \mathrm{C}$ pair (orange)

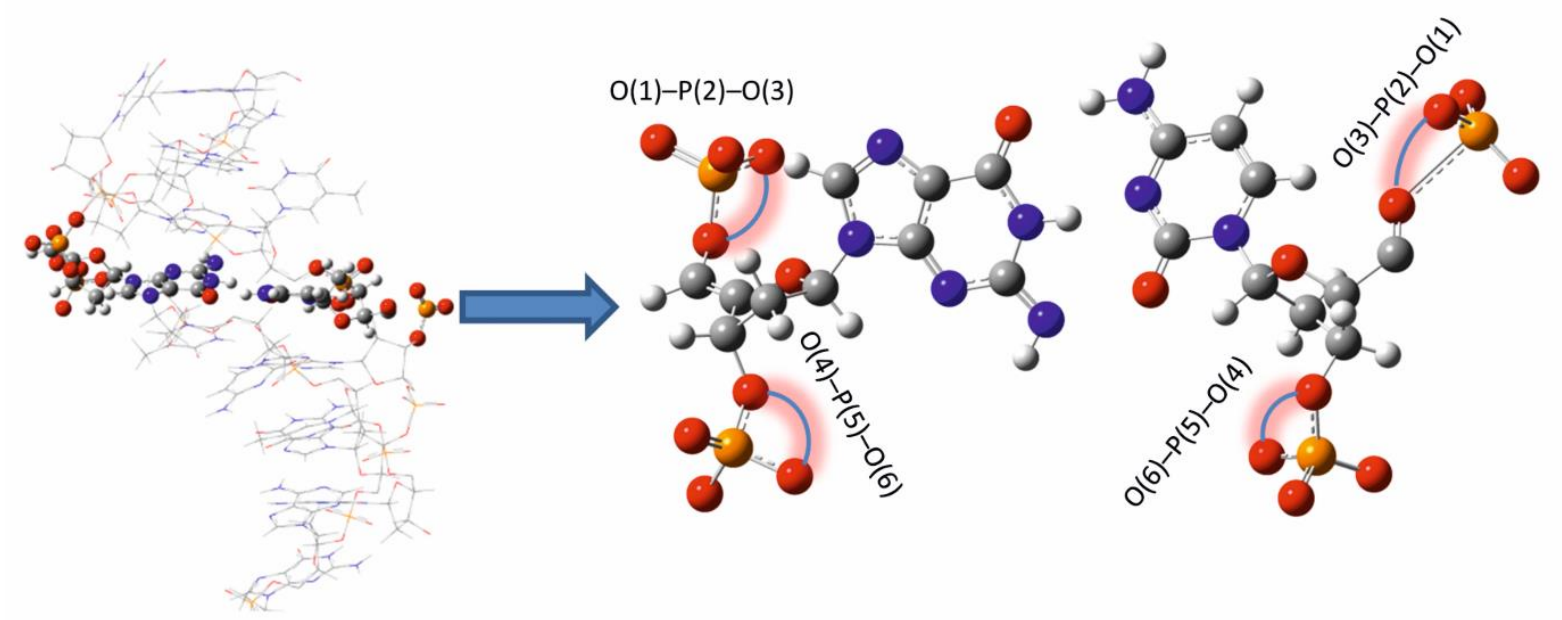

Figure 9. Schematic model of the theoretical molecular system of DNA (left) with $\bullet_{\mathrm{G}^{2} 2} \mathrm{C}$ pair (right) treated quantum mechanically 


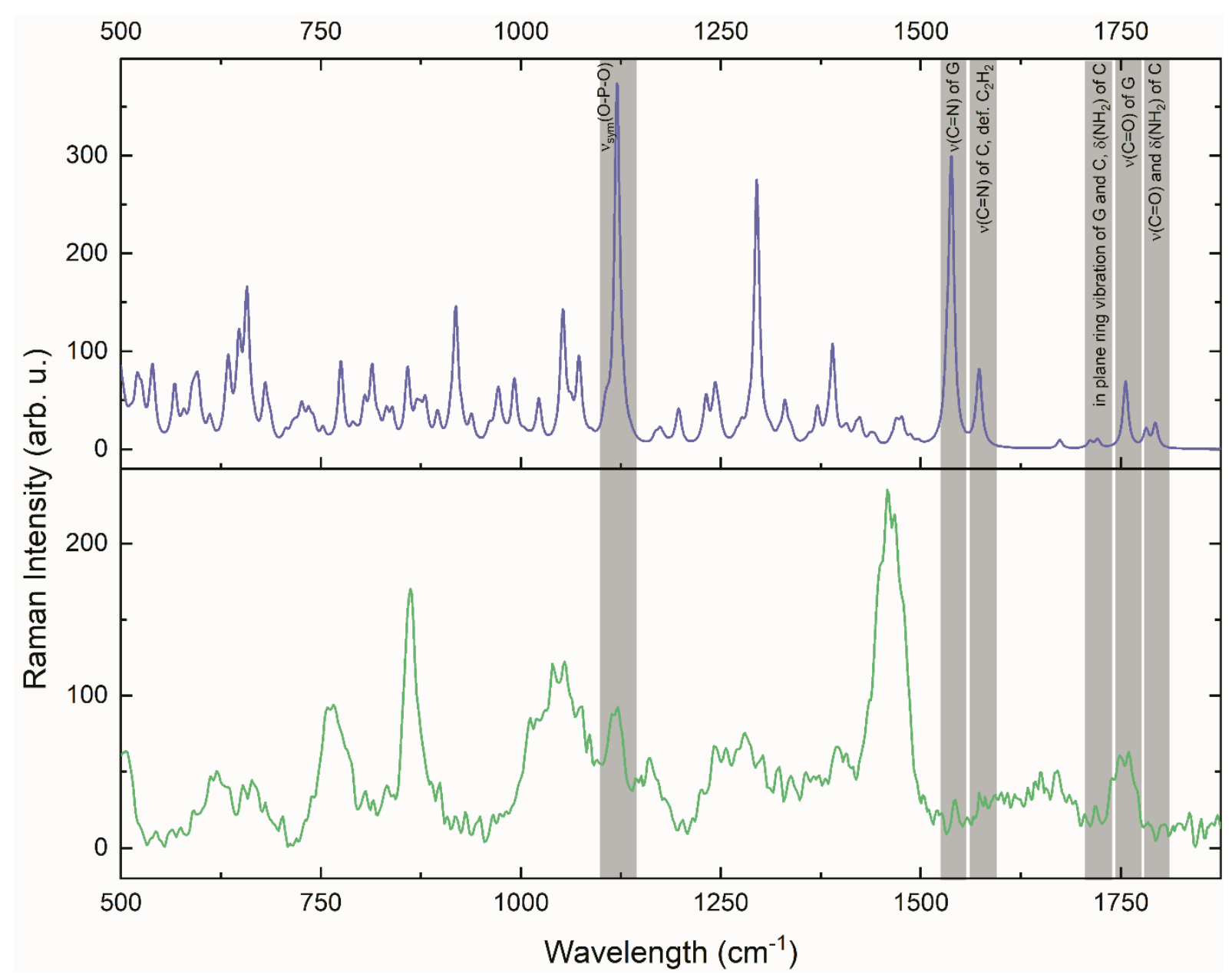

Figure 10. The comparison of spectra of DNA irradiated with the dose of 4000 protons (lime green) with calculated Raman spectrum of damaged DNA with $\cdot \mathrm{G}_{\mathrm{N} 1, \mathrm{~N} 2} \mathrm{C}$ pair (lilac)

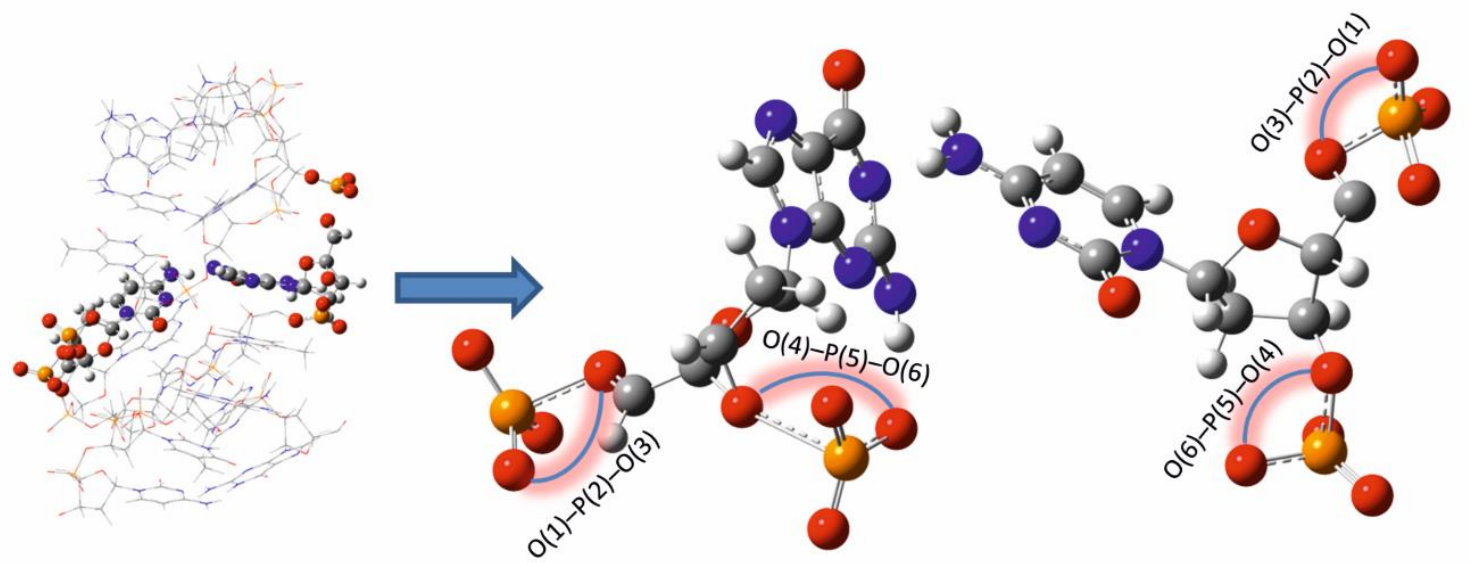

Figure 11. Schematic model of the theoretical molecular system of DNA (left) with $\bullet \mathrm{G}_{\mathrm{N} 1, \mathrm{~N} 2} \mathrm{C}$ pair (right) treated quantum mechanically 